удК 339.942

\title{
Ірина Олегівна ІВАЩУК
}

доктор економічних наук, професор, професор кафедри міжнародної економіки, Тернопільський національний економічний університет

E-mail: iryna.iva2@gmail.com

\section{Андрій Дмитрович ВОЙЦЕЩУК}

кандидат економічних наук, доцент,

директор Департаменту спеціалізованої підготовки та кінологічного забезпечення ДФС

E-mail: v_and@i.ua

\section{Віталій Зіновійович ЗАПУХЛЯК}

кандидат економічних наук,

генеральний директор ТзДВ «Івано-Франківське обласне підприємство автобусних станцій», Радник Посольства Республіки Хорватії в Україні

E-mail: v.zapukhlyak@gmail.com

\section{ПРОСТОРОВІ АСИМЕТРІЇ РЕГІОНАЛЬНОЇ ЕКОНОМІЧНОЇ ІНТЕГРАЦІЇ}

Іващук, I. О. Просторові асиметрії регіональної економічної інтеграції [Текст] / Ірина Олегівна Іващук, Андрій Дмитрович Войцещук, Віталій Зіновійович Запухляк // Економічний аналіз: зб. наук. праць / Тернопільський національний економічний університет; редкол.: О. В. Ярощук (голов. ред.) та ін. Тернопіль: Видавничо-поліграфічний центр Тернопільського національного економічного університету «Економічна думка», 2017. - Том 27. - № 3. - С. 266-275. - ISSN 1993-0259.

\section{Анотація}

Розглянуто об'єктивні передумови регіоналізації в глобальному просторі. Розкрито наслідки та виклики процесів регіональної економічної інтеграції для країн. Обгрунтовано важливість узгодження цілей регіональної економічної інтеграції та національної економічної політики. Аргументовано роль інтеграції у лібералізації торгівлі через зниження тарифних бар'єрів. Окреслено регіональні асиметрії глобального економічного розвитку. Проаналізовано стан розвитку регіональних торговельних угод останніх десятиліть, що дозволило виокремити труднощі функціонування інтеграційних об'єднань у сучасних умовах та обгрунтувати, що в кожному регіоні є свої особливості, що наведено на прикладі Європейського Союзу, країн-членів НАФТА, інтеграції в країнах Латинської Америки. Оцінено індекс регіональної інтеграції в Африці, що дозволило виявити значні відмінності серед груп країн. 3’ясовано особливості Транс-Тихоокеанського партнерства та умови співробітництва краӥн.

Ключові слова: глобальний простір; економічна інтеграція; індекс регіональної інтеграції; лібералізація торгівлі; регіональна асиметрія економічного розвитку; регіональні інтеграційні об'єднання; регіональні торговельні угоди. 


\title{
Iryna Olehivna IVASHCHUK
}

Doctor of Sciences (Economics),

Associate Professor,

Ternopil National Economic University

E-mail: iryna.iva2@gmail.com

\section{Andriy Dmytrovych VOYTSESHCHUK}

\author{
$\mathrm{PhD}$ in Economics, \\ Associate Professor, \\ Director of Department for Specialized Training and Canine Services of the State Fiscal Service of Ukraine \\ E-mail: v_and@i.ua
}

\section{Vitaliy Zinoviiovych ZAPUKHLYAK}

$\mathrm{PhD}$ in Economics, CEO,

Ivano-Frankivsk Regional Enterprise of Bus Stations, Advisor,

Embassy of the Republic of Croatia in Ukraine

E-mail: v.zapukhlyak@gmail.com

\section{SPACE ASYMMETRIES OF REGIONAL ECONOMIC INTEGRATION}

\begin{abstract}
The objective preconditions of regionalization in the global space are considered in the article. The consequences and challenges of regional economic integration processes for the countries are revealed. The importance of coordinating the objectives of regional economic integration and national economic policy is substantiated. The role of integration in the liberalization of trade through the reduction of tariff barriers is argued. The regional asymmetries of global economic development are outlined. The state of development of regional trade agreements in the last decades is analysed. This analysis has made it possible to determine the difficulties of functioning of integration associations in modern conditions and to substantiate that each region has its own peculiarities, as shown by the example of the European Union, the member countries of NAFTA, integration in the countries of Latin America . The index of regional integration in Africa has been estimated. It allowed revealing significant differences among the groups of countries. The peculiarities of the Trans-Pacific Partnership and the conditions of cooperation of the countries have been clarified.
\end{abstract}

Keywords: global space; economic integration; regional integration index; trade liberalization; regional asymmetry of economic development; regional integration associations; regional trade agreements.

\section{JEL classification: F02, F15}

\section{Вступ}

Інтеграція країн у систему міжнародних економічних відносин визначається їхніми пріоритетами, можливостями та цілями. На сучасному етапі розвитку світового господарства не усі країни змогли пройти прискорену модернізацію та імплементацію світових стандартів побудови економічної системи, розробити механізми побудови взаємовигідних відносин з іншими країнами, що позначилося на зміні умов їхнього позиціювання у глобальній економіці. Асиметрії та соціальноекономічна нерівність стала характерною рисою XXI ст., а глобальна політика розвитку має суперечливий та нерівномірний за наслідками характер. Тому одним із варіантів успішної глобальної інтеграції для більшості країн світу залишається вступ у міжнародні організації та регіональні альянси, укладення та виконання міжнародних торговельних угод.

\section{Мета та завдання статті}

Мета статті - це ідентифікація просторових асиметрій процесів регіональної економічної інтеграції.

\section{Виклад основного матеріалу дослідження}

Питання глобальної інтеграції та регіональної економічної інтеграції досліджували у своїх роботах відомі зарубіжні та вітчизняні вчені, серед яких можна виокремити роботи Б. Баласса, 
О. Булатової, Дж. Вайнера, І. Гладій, П. Кругмана, М. Лизун, Д. Лук'яненка, Ю. Пахомова, Н. Резнікової, $€$. Савельєва, В. Сіденка, Дж. Стигліца, С. Хантінгтона, В. Чужикова та інших. Незважаючи на значну кількість праць як зарубіжних, так і вітчизняних вчених із зазначеної проблематики, окремі аспекти залишаються недостатньо дослідженими, зокрема підходи до оцінювання просторових асиметрій, зумовлених процесами регіональної інтеграції під впливом глобалізації. Також не досягнуто консенсусу щодо позитивного впливу регіональної інтеграції на економічний розвиток.

Глобальний простір уміщує всі країни світу, які об'єктивно відрізняються низкою характеристик між собою, відповідно, кожна з них по-різному інтегрується у світове господарство. Для світу глобалізація принесла такі значущі події, як: збільшення міжнародного обміну товарами, послугами, пришвидшення переміщення людського капіталу; інтернаціоналізація виробництва та активізація інвестування; зростання політичної конвергенції між країнами; інтеграція фінансових (висока) та інших (меншою мірою) ринків [1].

Відсутність ефективного глобального управління змушує країни об'єднуватися, щоби реалізувати свій потенціал, відкриваючи нові можливості через інтеграційні процеси, але при цьому досягаються і спільні цілі об'єднання завдяки спільним зусиллям країн-членів. Зазначимо, що не існує єдиних правил у світі, як країнам обирати форму регіональної інтеграції, так само очевидним $\epsilon$ те, що кожне з інтеграційних об'єднань обирає свою стратегію утворення та розвитку, і це часто залежить від рівня економічного розвитку країн. Для країн, що розвиваються, регіональна інтеграція несе багатообіцяючі перспективи, але вони не завжди здатні розробити і впровадити ефективні механізми, які коригуватимуть процес переходу до обраного типу інтеграції та мінімізувати ризики. Іноземні дослідники до таких ключових питань відносять: макроекономічну стабільність, галузеві коригування, інвестиції в інфраструктуру та людський капітал, скорочення бідності та утвердження соціальної справедливості; управління, тому успішність інтеграції залежить і від макроекономічних реформ [2; 3]. На управлінських функціях держави наголошує і відомий економіст, дослідник економічних процесів та інтеграції країн Латинської Америки Енріке Іглесіас, бо державне управління є інституційною платформою для реалізації державної політики [4]. Питання залучення країн у світове господарство через інструменти регіональної економічної інтеграції залежить і від стану політичної стабільності у світі. Як приклад дослідник наводить ситуацію із країнами Латинської Америки, які відчули низку потрясінь через зазначену причину, переживши «шок міжнародних фінансів», «технологічний шок», «ліберальний шок», адже реформи країн цього регіону пройшли через досить багато помилок. Саме тому процес інтеграції на початку XXI ст. набував нових ознак і повинен поєднувати участь у межах СОТ (мова йшла про раунд Доха), створення зони вільної торгівлі «Північ-Південь» та спільного ринку між субрегіональними групами. Водночас, країни ідуть на численні поступки, аби тільки ввійти в єдину глобальну систему, брати участь у формуванні світового порядку, проте важливим $є$ обрання парадигми розвитку.

Країни, завдяки процесам регіональної інтеграції, максимально наближаються одна до одної, уніфікуючи як нормативно-правовий базис, так і інституційний, модернізуючи його відповідно до найуспішніших практик, наслідуючи економічні та соціальні реформи. Такі процеси несуть і певні загрози для країн, особливо, якщо вони відрізняються рівнями економічного розвитку. Мова йде про узгодження регіональної інтеграції та національної політики, і механізми узгодження й модель поведінки кожна країна чи об'єднання обирають самі (це залежить і від рівня асиметрії - чи вона зростаю чи спадає, чи передбачає угода про вільну торгівлю якісь компенсаційні механізми для країн, чи передбачає політика макроекономічної стабілізації активну регіональну політику і т. ін.) [5].

Так здебільшого процеси інтеграції ставлять своїм завданням покращення умов співпраці через усунення митно-тарифних та нетарифних бар'єрів, які мають подвійне значення: вони як стимулюють розвиток національної системи господарювання та позитивно впливають на стабілізацію національної економіки, так і стримують надмірне проникнення іноземних товарів на національний ринок, створюючи передумови для добросовісної конкуренції, захищаючи національного товаровиробника чи національний ринок, підвищуючи ефективність вітчизняного виробництва. В умовах, коли відсутнє чітке розуміння, яку ж політику із відповідними інструментами слід застосовувати при побудові відносин з іншими країнами на конкретному етапі розвитку, ставить ці країни в залежність від їхніх зобов'язань у межах участі в міжнародних економічних організаціях. Водночас зазначимо, що взаємовигідна співпраця для країн, як правило, означає використання потенціалу одна одної, але за взаємної або ж вимушеної згоди (наприклад, дотримання вимог Світової організації торгівлі щодо рівня зв'язаних тарифів, застосування субсидійних заходів). Щодо політики протекціонізму у відносинах між країнами, то лібералізація, яка була прийнятною до світової економічної кризи 2007-2008 рр., актуалізувала питання захисту національних ринків та інтересів, проте з 2011 р. обмежувальні заходи мали спадну тенденцію. Наприклад, в інвестиційній сфері за дослідженнями ЮНКТАД у 2015 р. 46 країн та економік вжили 96 заходів щодо регулювання інвестицій, причому 71 - були спрямовані на лібералізацію, 13 - мали обмежувальний характер (2 заходи у 2001 р.), 12 - були нейтральними [6]. 
Регіональні асиметрії економічного розвитку та залучення у систему світогосподарських відносин залишаються важливою проблемою, адже навіть за умови об'єднання та укладення відповідних угод серед країн-підписантів завжди $€$ ті, хто залишається на так званій периферії за показниками розвитку. Водночас ці країни мають найбільший потенціал розвитку, бо додаткові ресурси можуть стати каталізатором проведення реформ і підвищення показників розвитку. За дослідженнями Світового банку регіональні асиметрії у рівнях економічного розвитку присутні впродовж тривалого періоду часу (рис. 1). Економічний чинник залишається одним із визначальних при розширенні участі країн у регіональних торговельних угодах, адже дозволяє поєднувати спільні інтереси, розвивати різні спільні проекти, а кожна з країн прагне отримати вигоду від участі.

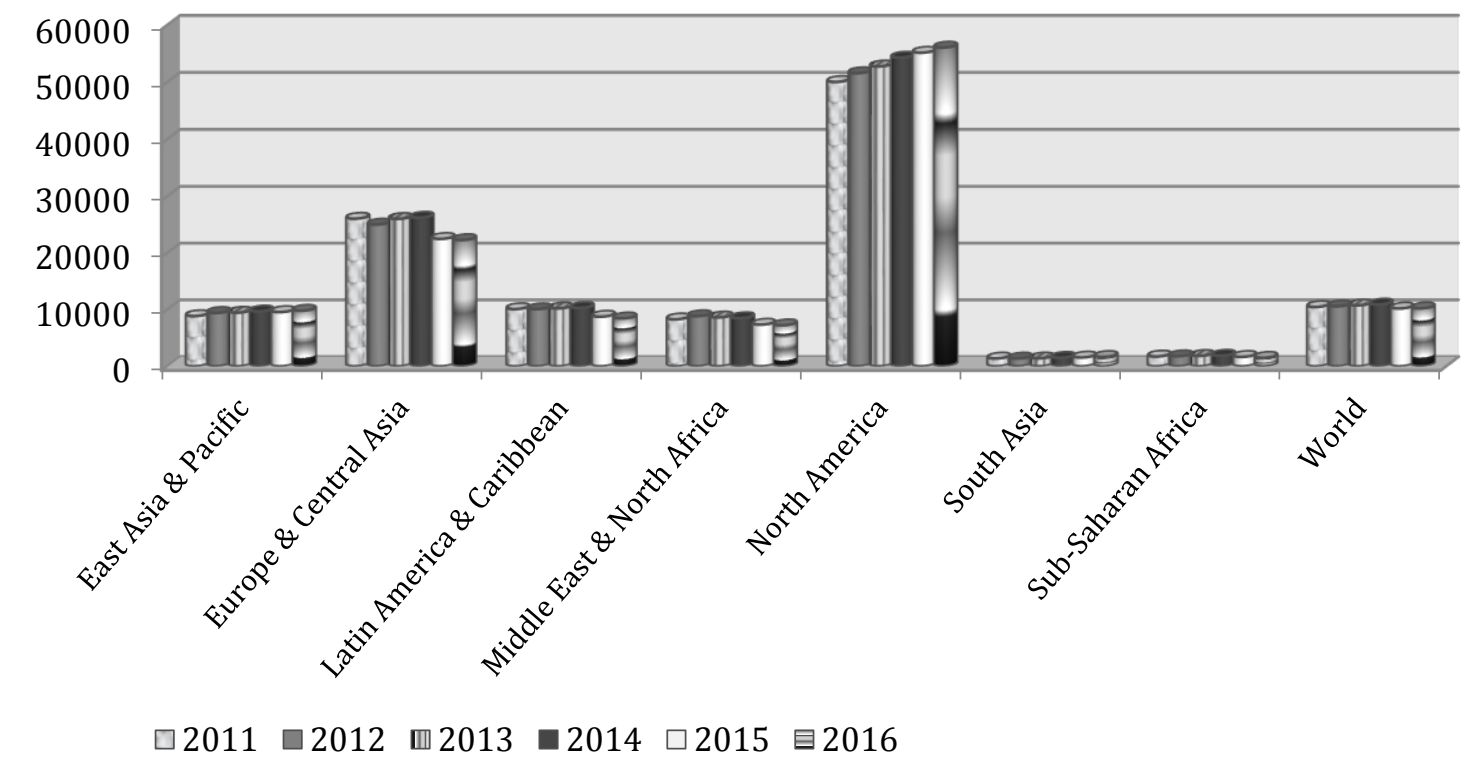

Рис. 1. Динаміка ВВП на одну особу (тис. дол. США)

\section{* Складено за даними Світового банку https://databank.worldbank.org/data/source/world-development-} indicators/preview/on.

Активізація процесів регіоналізації на початку XXI ст. стала об’єктивним процесом, адже країни отримали нові можливості для комунікації та розвитку. Торговельні перемовини в межах різноманітних форм інтеграції стали причиною утворення більшості з них. Водночас не усі регіональні торгові угоди $\epsilon$ діючими (рис. 2). Найактивніше регіональні торгові угоди укладаються в країнах Європи (на них припадає 20 \% усіх діючих РТУ), Східної Азії (17 \%), Південної Америки (12 \%) [7].

Як показує практика, багато інтеграційних об'єднань переживають у своїй діяльності кілька складних тенденцій: неузгодженість інтересів країн-учасниць групи та ідеологічні непорозуміння; низька ефективність від спрощення митних формальностей та умов переміщення товарів у межах групи, що проявляється у відсутності помітної інвестиційної та зовнішньоторговельної активності; нерозвинена інфраструктурна складова; низький соціальний ефект від інтеграції. Прикладом слабких результатів інтеграції для торгівлі в межах інтеграційних угрупувань є країни Африки (табл. 1), адже торгівля в межах групи $є$ не настільки значною, проте вона $є$ значною в межах певного регіону (очевидно, тут важливу роль відіграють питання транспортування). Наведені дані вказують на те, що при здійсненні зовнішньоторговельної політики, зокрема експорту товарів, кожне з об'єднань обирає свою стратегію, який регіон для збуту обирати, чому передує поглиблений аналіз та розрахунки.

Однак інтеграція для Африки залишається в числі пріоритетних завдань, про що наголошується Економічною комісією ООН для Африки. Для оцінки рівня її регіональної інтеграції використовується індекс, який охоплює п'ять напрямів (торговельна інтеграція, регіональна інфраструктура, виробнича інтеграція, вільне переміщення людей, фінансова інтеграція), які є важливими для ідентифікації рівня, та 16 показників (рис. 3).

Розрахунок індексу регіональної інтеграції вказує на значні відмінності серед груп країн африканського континенту та дає змогу з'ясувати ті напрями, за якими у кожної групи є відставання і на яких слід зосередити більшу увагу. Середнє значення індексу становить 0,470, що є дуже низьким, якщо врахувати, що шкала індексу 0 (низький рівень інтеграції) - 1(високий рівень) (табл. 2). 


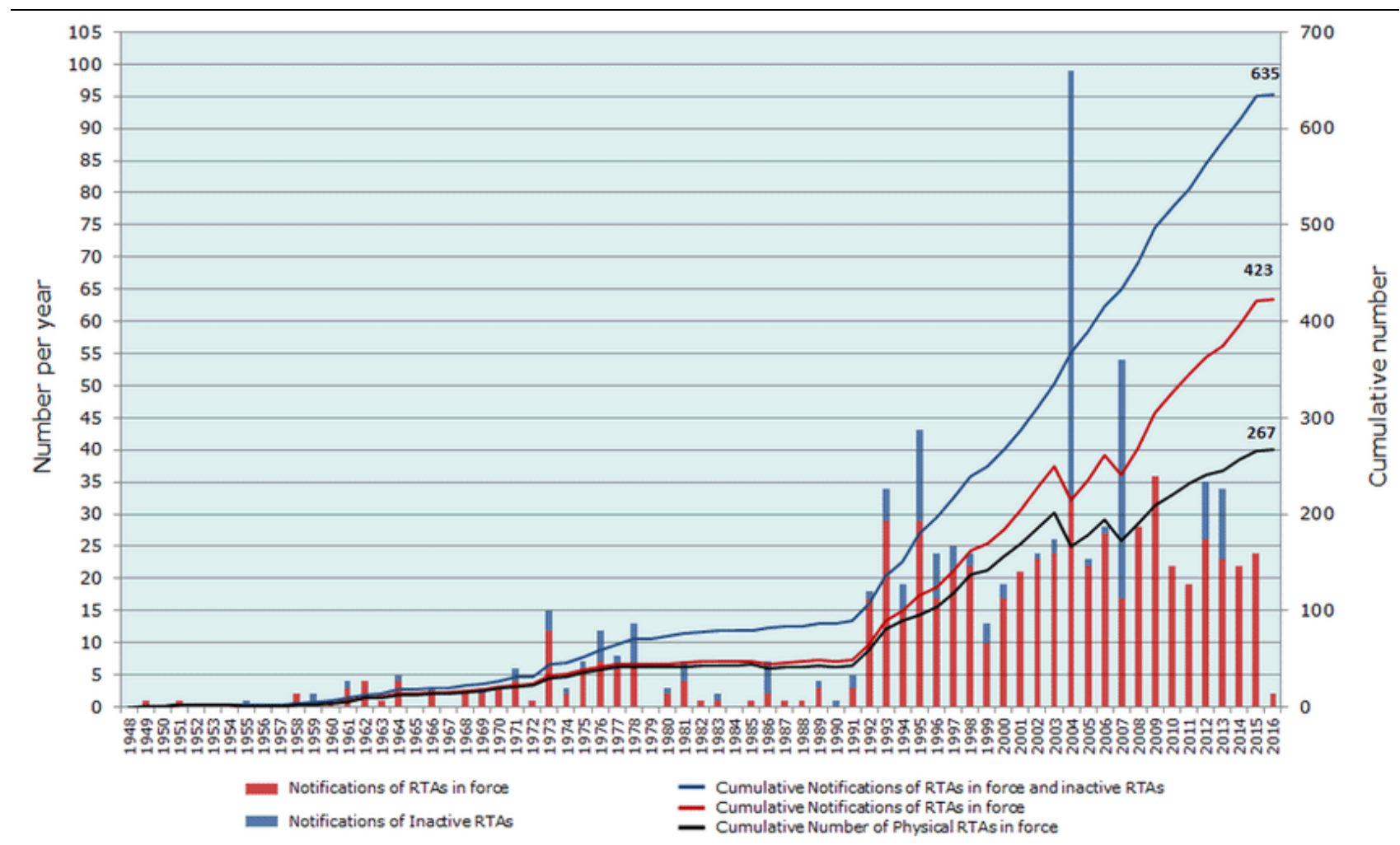

Рис. 2. Динаміка функціонування регіональних торговельних угод, 1948-2016 рр.

*Складено за даними Світового банку https://databank.worldbank.org/data/source/world-developmentindicators/preview/on.

Таблиця 1. Динаміка експорту товарів в інтеграційних угрупуваннях

\begin{tabular}{|c|c|c|c|c|c|c|c|c|c|c|c|c|c|c|}
\hline & \multicolumn{11}{|c|}{ Експорт товарів - Intra-group, \% } & \multicolumn{3}{|c|}{2016 p. } \\
\hline & $\begin{array}{l}\dot{2} \\
\text { } \\
\text { ○ }\end{array}$ & $\begin{array}{l}\dot{2} \\
\dot{8} \\
\stackrel{2}{N}\end{array}$ & 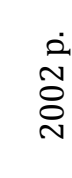 & $\begin{array}{l}\dot{2} \\
\text { o̊ } \\
\text { ¿े }\end{array}$ & $\begin{array}{l}\dot{e} \\
\stackrel{0}{0} \\
\stackrel{0}{v}\end{array}$ & $\begin{array}{l}\dot{e} \\
\hat{O} \\
\stackrel{N}{2}\end{array}$ & $\begin{array}{l}\dot{e} \\
\infty \\
\stackrel{ᄋ}{0}\end{array}$ & $\begin{array}{l}\dot{2} \\
\text { o } \\
\text { Oे }\end{array}$ & 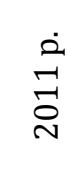 & $\stackrel{\dot{a}}{\stackrel{m}{2}}$ & $\begin{array}{l}\dot{2} \\
\text { Ln } \\
\stackrel{2}{0}\end{array}$ & 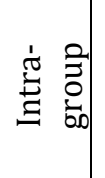 & 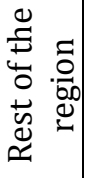 & 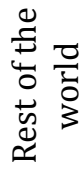 \\
\hline $\begin{array}{l}\text { ASEAN +China, } \\
\text { Japan and } \\
\text { Republic of Korea }\end{array}$ & 33,6 & 33,8 & 34,3 & 35,0 & 33,8 & 33,4 & 34,3 & 34,9 & 36,0 & 35,6 & 34,0 & 34,4 & 39,3 & 65,6 \\
\hline CARICOM & 15,8 & 15,8 & 14,3 & 13,8 & 13,1 & 11,7 & 14,0 & 12,0 & 11,9 & 13,3 & 12,2 & 12,2 & 82,6 & 87,8 \\
\hline CEMAC & 1,2 & 1,7 & 2,0 & 2,1 & 1,6 & 2,5 & 2,6 & 3,4 & 3,6 & 2,7 & 3,5 & 3,5 & 53,0 & 96,5 \\
\hline COMESA & 4,9 & 5,7 & 6,3 & 5,8 & 5,4 & 4,9 & 5,3 & 6,9 & 9,1 & 9,1 & 11,5 & 9,7 & 50,9 & 90,3 \\
\hline ECCAS & 0,9 & 1,2 & 1,2 & 1,3 & 1,1 & 1,4 & 1,3 & 2,1 & 2,2 & 1,7 & 2,1 & 1,9 & 65,2 & 98,1 \\
\hline ECOWAS & 9,4 & 9,7 & 10,9 & 10,0 & 8,5 & 8,4 & 9,2 & 9,7 & 7,3 & 9,2 & 10,0 & 11,2 & 36,0 & 88,8 \\
\hline EU28 & 67,7 & 67,3 & 67,5 & 68,6 & 68,1 & 68,2 & 67,3 & 66,6 & 63,8 & 61,5 & 62,6 & 63,5 & 9,5 & 36,5 \\
\hline MERCOSUR & 18,1 & 16,1 & 11,3 & 11,1 & 12,9 & 13,7 & 13,8 & 14,5 & 14,0 & 13,7 & 13,3 & 13,1 & 64,9 & 86,9 \\
\hline NAFTA & 55,8 & 55,1 & 56,1 & 55,9 & 53,9 & 51,3 & 49,5 & 48,0 & 48,3 & 49,2 & 50,4 & 50,2 & 12,6 & 49,8 \\
\hline SACU & 3,0 & 2,9 & 2,3 & 2,7 & 2,2 & 3,0 & 3,2 & 3,7 & 12,5 & 14,2 & 16,3 & 15,4 & 48,7 & 84,6 \\
\hline $\begin{array}{l}\text { TPP (Trans- } \\
\text { Pacific } \\
\text { Partnership) }\end{array}$ & 14,9 & 14,4 & 14,3 & 14,0 & 14,8 & 15,1 & 16,2 & 15,9 & 16,1 & 15,2 & 14,9 & 14,5 &.. & 85,5 \\
\hline
\end{tabular}

${ }^{*}$ Складено за UNCTADstat: Intra-trade of regional and trade groups by product [Electronic Resource]. - Mode of access: https://unctadstat.unctad.org/wds/TableViewer/tableView.aspx?ReportId=24397. 


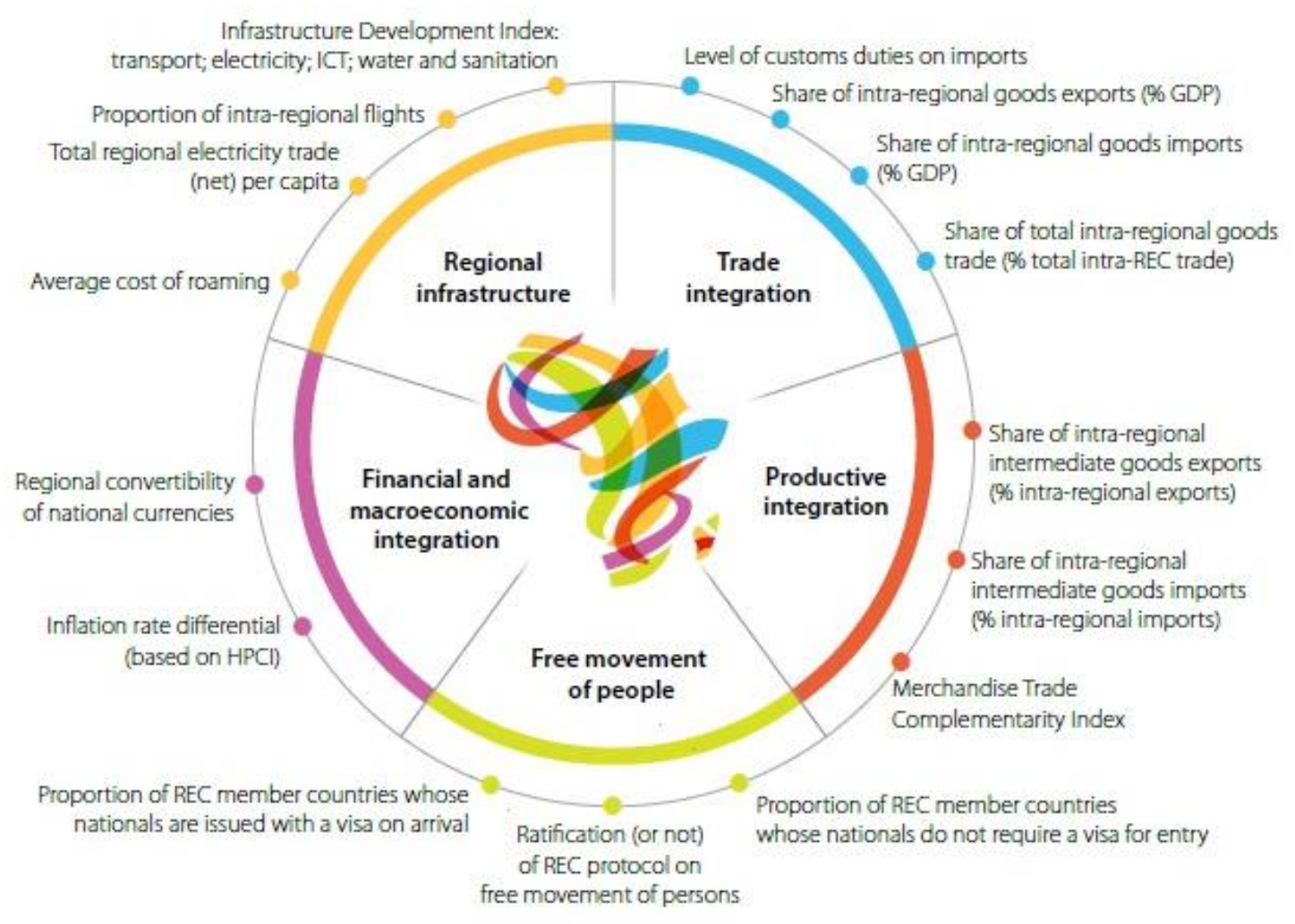

Рис. 3. Структура індексу регіональної інтеграції в Африці [8]

Серед усіх груп лише для трьох з них індекс перевищує середнє значення, проте ненабагато. Серед складових індексу найслабшою $є$ виробнича інтеграції (середнє значення 0,384) та фінансова $(0,381)$, що пояснюється слабким розвитком фінансового сектору в країнах цього регіону. Щодо стану інфраструктури, то її низький рівень стримує не лише процеси інтеграції, а й економічного зростання. Процеси регіональної інтеграції ускладнюються тим, що багато торговельних угод на практиці не виконуються, зберігається високий рівень нетарифного захисту економік, країни змінюють свою політику в частині встановлення митних тарифів, одночасно беруть участь у кількох блоках, суттєво відрізняються державна політика та темпи економічного зростання між різними регіонами Африки. Майбутнє інтеграції на африканському континенті буде залежати від макроекономічного управління та диверсифікації економік країн, розбудови інфраструктури, управлінських рішень у підвищенні добробуту.

Таблиця 2. Значення індексу регіональної інтеграції в Африці [8]

\begin{tabular}{|l|c|c|c|c|c|c|}
\hline & $\begin{array}{c}\text { Індекс } \\
\text { регіональної } \\
\text { інтеграції }\end{array}$ & $\begin{array}{c}\text { Торговельна } \\
\text { інтеграція }\end{array}$ & $\begin{array}{c}\text { Регіональна } \\
\text { інфраструк- } \\
\text { тура }\end{array}$ & $\begin{array}{c}\text { Виробнича } \\
\text { інтеграція }\end{array}$ & $\begin{array}{c}\text { Вільне } \\
\text { переміщення } \\
\text { людей }\end{array}$ & $\begin{array}{c}\text { Фінансова } \\
\text { інтеграція }\end{array}$ \\
\hline CEN-SAD & 0,395 & 0,353 & 0,251 & 0,247 & 0,479 & 0,524 \\
\hline COMESA & 0,415 & 0,572 & 0,439 & 0,452 & 0,268 & 0,343 \\
\hline EAC & 0,540 & 0,780 & 0,496 & 0,553 & 0,715 & 0,156 \\
\hline ECCAS & 0,454 & 0,526 & 0,451 & 0,293 & 0,400 & 0,599 \\
\hline ECOWAS & 0,509 & 0,442 & 0,426 & 0,265 & 0,800 & 0,611 \\
\hline IGAD & 0,457 & 0,505 & 0,630 & 0,434 & 0,454 & 0,221 \\
\hline SADC & 0,531 & 0,508 & 0,502 & 0,350 & 0,530 & 0,397 \\
\hline UMA & 0,459 & 0,631 & 0,491 & 0,481 & 0,493 & 0,199 \\
\hline \multicolumn{1}{|c|}{ Average } & 0,470 & 0,540 & 0,461 & 0,384 & 0,517 & 0,381 \\
\hline
\end{tabular}

Особливістю функціонування регіональних інтеграційних об’єднань $є$ й те, що кожне з них мало власні передумови для інтеграції. Наприклад, об'єднання NAFTA мало на меті створення сприятливих умов для розвитку торгівлі та зменшення тарифних бар'єрів, що і було досягнуто (зросло залучення інвестицій та обсяги виробництва, зменшення тарифних бар'єрів між країнами суттєво вплинуло на цінову політику, урядові контракти стали доступними для всіх країн-членів), проте участь країн у групі виявилася досить нерівною, що підтверджується просторовими та галузевими асиметріями, і для 
Мексики вона принесла чимало викликів і ризиків (варто згадати проблеми із сільським господарством, із міграцією та ін.). Окрім того, створення Транс-Тихоокеанського партнерства (Trans-Pacific Partnership) несе певні виклики для NAFTA, тому очевидно, що найближчі роки буде переглянута стратегія угрупування із акцентом не лише на торгівлі, а й на зростанні доходів населення, інфраструктурному середовищі, зеленій економіці, енергетичному ринку із створенням зони розвитку відновлювальної енергетики, освітній сфері [9]. Щодо Транс-Тихоокеанського партнерства, то його ідея була висунута США ще у 2008 р., а у 2016 р. відбулося підписання угоди про його створення 12 країнами (рис. 4), однак вже у січні 2017 р. США вийшли із партнерства.
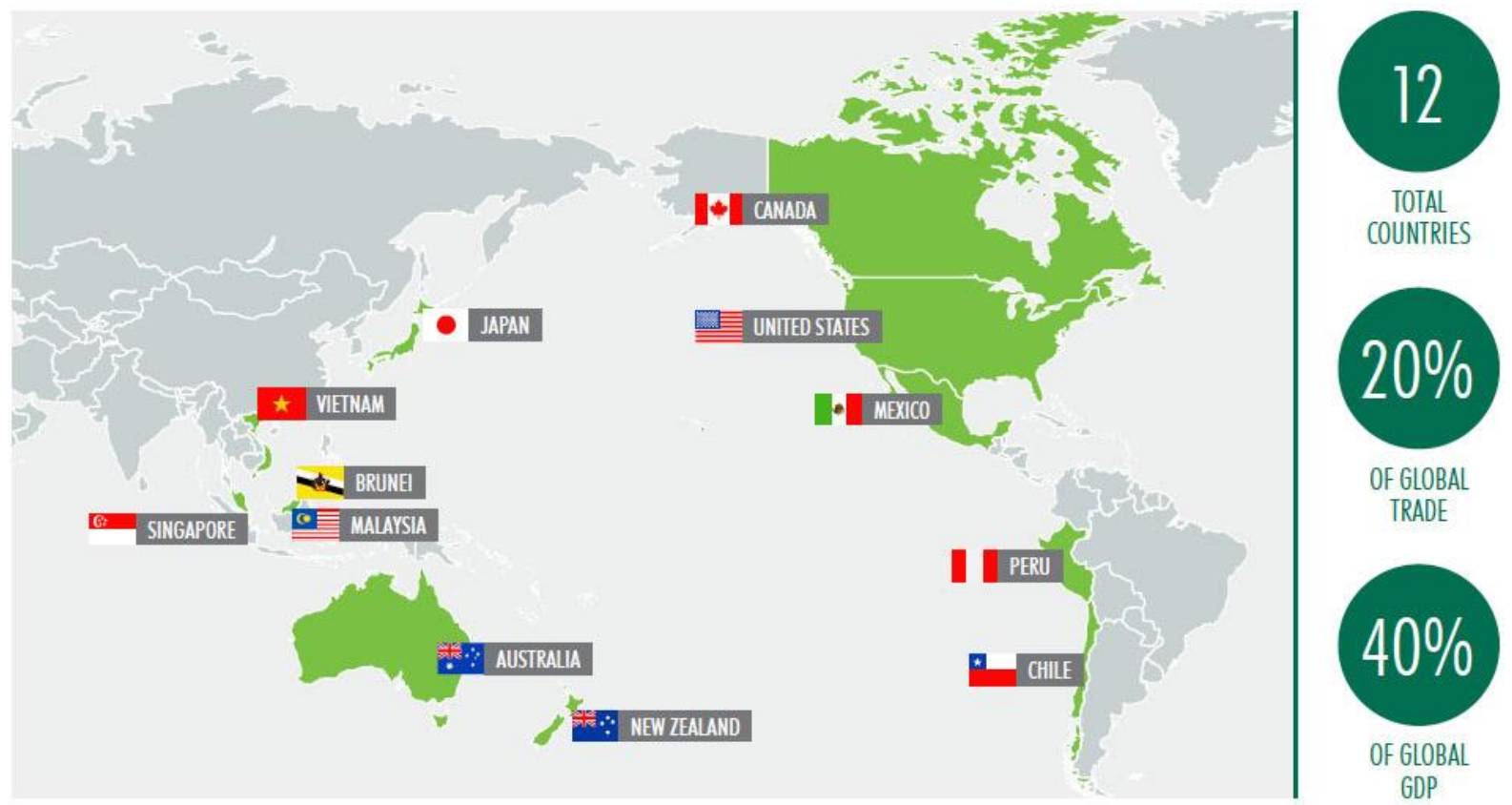
Рис. 4. Країни-учасниці підписання угоди про Транс-Тихоокеанське партнерство
(Trans-Pacific Partnership) у 2016 p. [10]

Водночас таке партнерство $є$ важливе для країн - членів ASEN, що стане додатковим поштовхом для проведення внутрішніх структурних реформ [11]. Щодо тарифної політики та умов торгівлі, то передбачається, що ТРР створить умови для суттєвого зниження тарифних ставок (до 99 \% ставок у торгівлі між країнами буде усунуто) відповідно до Угоди (рис. 5) (проте вихід США у 2017 р. 3 угоди вніс значні зміни в лібералізацію митного тарифу), ефективного проходження товарів, поводження із експрес-відправленнями, електронної обробки митної документації, запровадження системи управління ризиками, забезпечення прозорості [12]. Але не усі країни отримують моментальні вигоди від партнерства (у розрахунках [13] наведено базовий рівень, який містить існуючі на момент дослідження торговельні угоди між країнами-членами ТРР, та прогноз із урахуванням сценарію реалізації угоди про партнерство).

Стратегічно така інтеграція в Тихоокеанському регіоні може вплинути на співробітництво Європейського Союзу з країнами-учасницями партнерства. Водночас приклад Європейського Союзу $є$ показовим щодо регіональної економічної інтеграції, де частка внутрішньогрупового експорту становить понад 60 \%, проте не слід забувати, що для вступу у ЄС країни проходять низку економічних і соціальних реформ, зобов'язані виконати цілий перелік встановлених зобов'язань, тому така інтеграція не є типовим прикладом для інших регіональних інтеграційних угрупувань. Політика інтеграції та соціально-економічного розвитку $Є C$ є тісно пов'язаними між собою. Окрім того, якщо проаналізувати географічну структуру експорту ЄС-28, то з 36,5 \% зі 100 \% припадає на країни поза ЄС, і лише 9,5 \% - на країни цього ж регіону. ЄС є прикладом, де проводилася поступова лібералізація зовнішньої торгівлі та розроблена спільна торговельна і митна політика щодо третіх країн, забезпечена висока мобільність капіталу та людських ресурсів, на інституційному рівні сформована міцна платформа для інтеграційних процесів, уніфіковано правила оподаткування, тарифний профіль Європейського Союзу характеризується 100 \% зв'язуванням тарифів, процес інтеграції розвивається на основі комплексного підходу, коли угоди охоплюють не лише питання торгівлі [15].

Водночас сьогодні відбувається відхід від класичного розуміння інтеграції, яка передбачає близькість територій, наближений рівень економічного розвитку тощо. Так, якщо раніше був ряд вимог, яким має відповідати регіональна економічна інтеграція (це спільність кордонів, схожий рівень розвитку учасниць, історично сформовані відносини між країнами тощо), то зараз щораз частіше ці 
вимоги не є обов'язковими. Прикладом такого інтеграційного альянсу є БРІКС [16], країни якого в процесі співробітництва змогли виробити механізми врахування спільних інтересів їх досягнення.

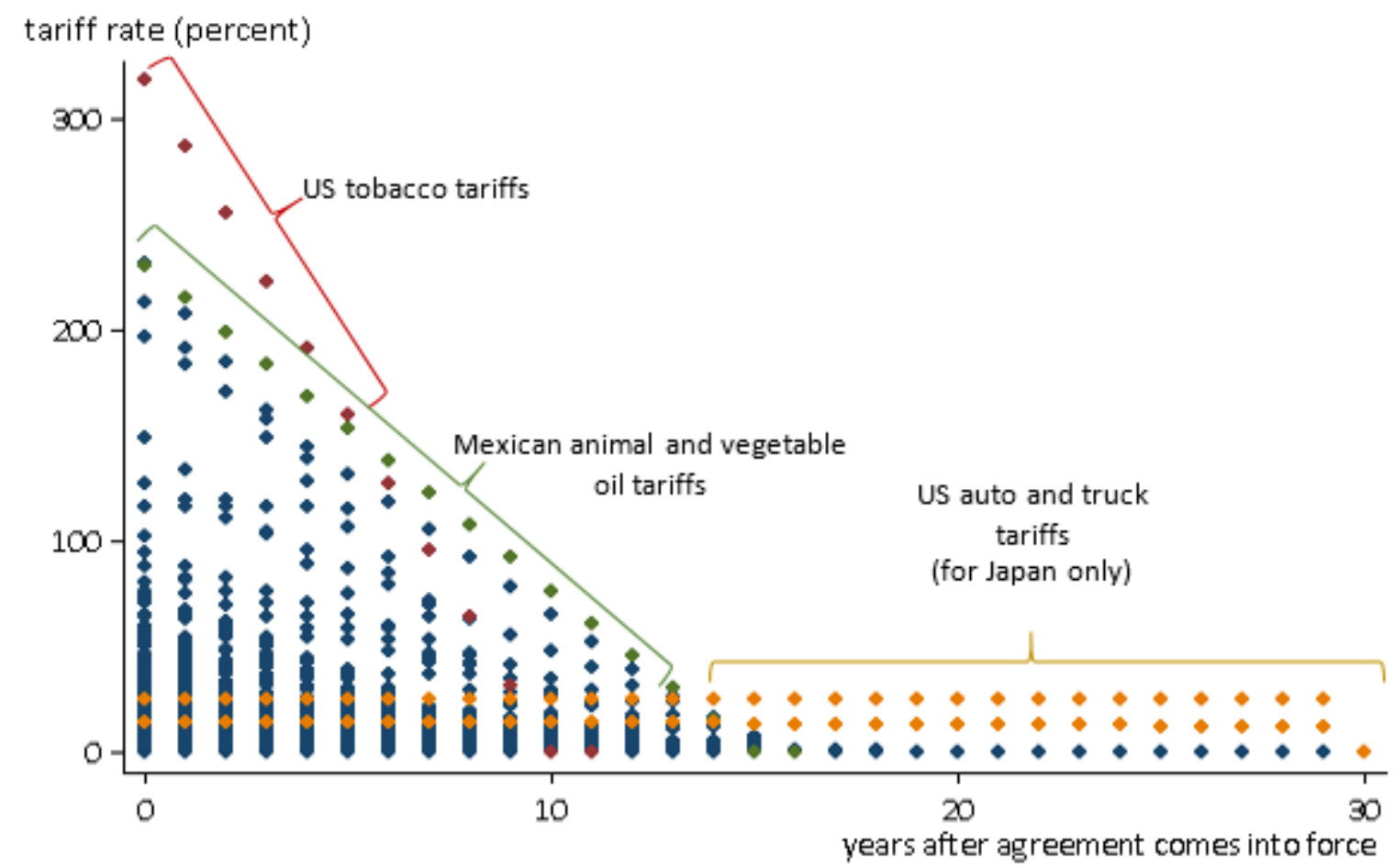

\section{Рис. 5. Зниження ставок мита в межах Транс-Тихоокеанського партнерства протягом 30 років 3 дня набуття чинності угоди (станом на 2016 р.) [14]}

*Графік відображає середні тарифні ставки для 6-значних кодів товарів).

\section{Висновки та перспективи подальших розвідок}

Проведений аналіз показав, що поряд із активізацією процесів глобалізації, зосередженням світової спільноти на перевагах участі у багатосторонньому співробітництві в рамках Світової організації торгівлі, регіоналізація залишається важливим вектором розвитку світового господарства, що підтверджує діалектичну єдність зазначених процесів. Країни, дотримуючись зобов'язань щодо лібералізації торговельних режимів відповідно до правил СОТ, не відкидають регіональну інтеграцію як спосіб налагодження взаємовигідних відносин в межах певної території. Водночас у процесі дослідження доведено існування просторової асиметрії процесів регіональної інтеграції, що зумовлено відмінними між інтеграційними об'єднаннями умовами та цілями створення, етапами інтеграції, які вони пройшли, що у підсумку може стати потенційною загрозою для майбутнього розвитку багатосторонньої торговельної системи. Вважаємо, що за таких умов неодмінно відбудеться вихід процесів економічної інтеграції за межі чітко окреслених теоретичними підходами до регіональної інтеграції територій (такі приклади уже є у світовій практиці), а також об'єднання країн із різним рівнем економічного розвитку, забезпечуючи якість укладених регіональних торговельних угод.

\section{Список літератури}

1. Sakbani, M. The global economic system: asymmetries and inconsistencies [Електронний ресурс] / Michael Sakbani // Foresight. - 2005. - Vol. 7 Issue: 1. - Р. 11-25. - Режим доступ: https://www.standrews.ac.uk/business/distance/Economics/Reading/Global\%20Economic\%20System.pdf.

2. Asymmetries in regional integration and local development / Paolo Giordano, Francesco Lanzafame, Jörg Meyer-Stamer [Електронний $\quad$ ресурс]. https://publications.iadb.org/publications/english/document/Asymmetries-in-Regional-Integration-andLocal-Development.pdf.

3. Trade for Development in Latin America and the Caribbean / David de Ferranti, Daniel Lederman, Guillermo Perry, and Rodrigo Suescún [Electronic Resource]. - Mode of access: https://www.ictsd.org/sites/default/files/event/2008/08/layout_agi.pdf.

4. Iglesias E. El papel del Estado y los paradigmas económicos en América Latina. - Revista de la CEPAL-90. Santiago de Chile, Diciembre 2006. [Electronic Resource]. - Mode of access: http://biblioteca.ues.edu.sv/revistas/107006431.pdf. 
5. Giordano, P. Asymmetries in regional integration and local development [Electronic Resource] / Paolo Giordano, Francesco Lanzafame, Jörg Meyer-Stamer. - Mode of access: https://publications.iadb.org/publications/english/document/Asymmetries-in-Regional-Integration-andLocal-Development.pdf.

6. World Investment Report 2016 - Investor Nationality: Policy Challenges [Electronic Resource]. - Mode of access: https://unctad.org/en/PublicationsLibrary/wir2016_en.pdf.

7. Recent Developments in Regional Trade Agreements (July-December 2016) [Electronic Resource]. - Mode of access:https://www.wto.org/english/tratop_e/region_e/rtajuly-dec16_e.pdf.

8. Africa Regional Integration Index - Report 2016 [Electronic Resource]. - Mode of access: http://repository.uneca.org/bitstream/handle/10855/23200/b11561531.pdf?sequence=1.

9. Clemente Ruíz. Productive Restructuring and Integration: NAFTA, 20 Years Later / Problemas del Desarrollo. - Volume 46 Number 180, January-March 2015. [Electronic Resource]. - Mode of access: Probdes.iiec.unam.mx/en/revistas/v45n180/body/v45n180a2_1.php.

10. How will the Trans-Pacific Partnership Impact Property Markets? [Electronic Resource]. - Mode of access: http://www.cbrecapitalwatch.com/?p=1976.

11. Sanchita Basu Das. The Trans-Pacific Partnership (TPP) Agreement Holds Strategic Underpinnings [Electronic Resource]. - $\quad$ Mode of https://www.iseas.edu.sg/images/pdf/ISEAS_Perspective_2016_22.pdf.

12. Fergusson, I. F. The Trans-Pacific Partnership (TPP): In Brief / Ian F. Fergusson, Mark A. McMinimy, Brock R. Williams. // Congressional Research Service. - 2005. - February 9. [Electronic Resource]. - Mode of access: https://fas.org/sgp/crs/row/R44278.pdf.

13. Petri, P. A. The Economic Effects of the Trans-Pacific Partnership: New Estimates [Electronic Resource] / Peter A. Petri, Michael G. Plummer. - Mode of access: https://piie.com/publications/wp/wp16-2.pdf.

14. Trans-Pacific Partnership: geopolitical implications for EU-US relations [Electronic Resource]. - Mode of access: http://www.europarl.europa.eu/RegData/etudes/STUD/2016/535008/EXPO_STU(2016)535008_EN.pdf.

15. Sanoussi, B. Is the EU a Model of Regional Integration? Risks and challenges [Electronic Resource] / Bilal Sanoussi. - Mode of access: https://ecdpm.org/wp-content/uploads/2013/11/EU-Model-RegionalIntegration-Risks-Challenges-2007-.pdf.

16. BRICS and the Global Economy [Electronic Resource]. - Mode of access: https://www.researchgate.net/publication/262643206_BRICS_and_the_Global_Economy.

\section{References}

1. Sakbani, Michael. (2005). The global economic system: asymmetries and inconsistencies. Foresight, 7(1), 1125 Retrieved from: https://www.standrews.ac.uk/business/distance/Economics/Reading/Global\%20Economic\%20System.pdf.

2. Giordano, Paolo, Lanzafame, Francesco, Meyer-Stamer, Jörg (n. d.). Asymmetries in regional integration and local development. Retrieved from: https://publications.iadb.org/publications/english/document/Asymmetries-in-Regional-Integration-andLocal-Development.pdf.

3. de Ferranti, David, Lederman, Daniel, Perry, Guillermo, and Suescún, Rodrigo (2008). Trade for Development in Latin America and the Caribbean. Retrieved https://www.ictsd.org/sites/default/files/event/2008/08/layout_agi.pdf.

4. Iglesias, E. (2006). El papel del Estado y los paradigmas económicos en América Latina. - Revista de la CEPAL-90. Santiago de Chile, Diciembre. http://biblioteca.ues.edu.sv/revistas/107006431.pdf.

5. Giordano, Paolo, Lanzafame, Francesco, Meyer-Stamer, Jörg (n.d.). Asymmetries in regional integration and local development. Retrieved from: https://publications.iadb.org/publications/english/document/Asymmetries-in-Regional-Integration-andLocal-Development.pdf.

6. World Investment Report 2016 - Investor Nationality: Policy Challenges. (2016). Retrieved from: https://unctad.org/en/PublicationsLibrary/wir2016_en.pdf.

7. Recent Developments in Regional Trade Agreements (July-December 2016). Retrieved from: https://www.wto.org/english/tratop_e/region_e/rtajuly-dec16_e.pdf.

8. Africa Regional Integration Index - Report 2016. (2016). Retrieved from: http://repository.uneca.org/bitstream/handle/10855/23200/b11561531.pdf?sequence=1.

9. Clemente, Ruíz. (2015). Productive Restructuring and Integration: NAFTA, 20 Years Later / Problemas del Desarrollo. - Volume 46 Number 180, January-March 2015. Retrieved from: Probdes.iiec.unam.mx/en/revistas/v45n180/body/v45n180a2_1.php. 
10. How will the Trans-Pacific Partnership Impact Property Markets? (1976). Retrieved from: http://www.cbrecapitalwatch.com/?p=1976.

11. Basu Das, Sanchita. (2016). The Trans-Pacific Partnership (TPP) Agreement Holds Strategic Underpinnings. Retrieved from: https://www.iseas.edu.sg/images/pdf/ISEAS_Perspective_2016_22.pdf.

12. Fergusson, Ian F., McMinimy, Mark A., Williams, Brock R. (2005). The Trans-Pacific Partnership (TPP): In Brief. Congressional Research Service. February 9. Retrieved from: https://fas.org/sgp/crs/row/R44278.pdf.

13. Petri, Peter A., Plummer, Michael G. (n.d.). The Economic Effects of the Trans-Pacific Partnership: New Estimates. Retrieved from: https://piie.com/publications/wp/wp16-2.pdf.

14. Trans-Pacific Partnership: geopolitical implications for EU-US relations. (2016). Retrieved from: http://www.europarl.europa.eu/RegData/etudes/STUD/2016/535008/EXPO_STU(2016)535008_EN.pdf.

15. Sanoussi Bilal. (2007). Is the EU a Model of Regional Integration? Risks and challenges. Retrieved from: https://ecdpm.org/wp-content/uploads/2013/11/EU-Model-Regional-Integration-Risks-Challenges-2007.pdf.

16. BRICS and the Global Economy. (n.d.). Retrieved from: https://www.researchgate.net/publication/262643206_BRICS_and_the_Global_Economy.

Стаття надійшла до редакції 07.10.2017 р. 